\title{
Use SOAPS Strategies to Improve the Reading Comprehension
}

\author{
${ }^{1}$ Rofina Jemamus, ${ }^{2}$ Hengki Wijaya, ${ }^{3}$ Harmelia Tulak \\ \{yovinyovina6@gmail.com¹,hengkiwijaya@sttjaffray.ac.id², tulakharmelia@gmail.com³ \\ Sekolah Tinggi Keguruan dan Ilmu Pendidikan YPUP Makassar, Indonesia ${ }^{1}$ \\ Sekolah Tinggi Filsafat Jaffray Makassar, Indonesia ${ }^{2}$ \\ Universitas Kristen Indonesia Toraja, Indonesia ${ }^{3}$
}

\begin{abstract}
This paper aims to see the effectiveness of the using strategy of the SOAPS to improve the reading comprehension of second-grade students at Satria Makassar High School in the academic year 2018/2019. This study used a pre-experimental procedure consisting of 20 students in one class. Researchers applied test reading material consisting of 30 multiple-choice items. The conclusions indicate that there are significant differences in student achievement in reading comprehension, where the post-test average score is higher than the pre-test $(71.30>51.55)$ based on the findings of this study.
\end{abstract}

Keywords: Strategy, Reading Comprehension, EFL, SOAPS

\section{Introduction}

Reading is an essential thing for students who master in learning English to get information. The teaching of reading aims to make students able to read English texts correctly and adequately. Reading helps students learn English. Reading consists of two processes, namely recognizing words and understanding words. Word recognition is the process of understanding how written symbols correspond to one's verbal language. The knowledge of concepts is related to the operation of understanding many words, a sentence, and relevant text.

Based on the views of Linse \& Nunan [1], reading is not only for fun or entertainment but also for information. When students read the text provided in the process of teaching reading, they will get relevant information that the author wants to convey. However, students must understand the meaning of writing as competence in reading.

Based on the practice of students as English teachers at Satria Makassar High School, the researchers found that students faced difficulties in reading comprehension in several texts, primarily narrative texts. As an EFL teacher, research uses SOAPS strategies to improve students' reading skills. Students need an approach of combining writing, speaking, and reading English texts and then relaying them by developing the ideas they get in class. Originally designed as a method for dissecting the work of professional writers, SOAPS provides concrete strategies to help students identify and use these main components as a basis for their writing. The limitations of this study do not test the writer's attitude in reading skills.

SOAPS Strategy is a strategy that can be used with any text. It means that students can understand the text and identify the elements of the text. Students also find the meaning and meaning of the text. The problem statement questions are: How is the effectiveness of the SOAPS Strategy in improving students' reading comprehension at Satria Makassar High School?

\section{Literature Review}

\section{Definition of reading}

Argument interpretation is a process that makes it easy for readers to combine information sourced from the text and their initial information to construct meaning [1]. The reader must know the data and ideas of the text to get the definition and the way the reader reads the text that has influenced their understanding. Furthermore, Brown [2], states that reading is also a skill that is naturally taught by the teacher. Students understand what is conveyed by the teacher. Thus reading is the process of getting new information or knowledge by reading texts. Besides, information or experience will be obtained in many aspects, such as newspapers on the use of technology, social media, and education.

\section{Definition of Reading Comprehension}

Reading comprehension is an advantage of students who support the success of one's education. With adequate reading skills, students can succeed in many fields of study. This skill is significantly essential in the 
areas of science and research. Many students lack prior knowledge and reading strategies to produce conclusions caused by a lack of students' understanding of science texts [3].

Westwood believes reading comprehension as a process of one's cognition as a reader consciously constructs meaning to form a deeper understanding of the frame of mind and information contained in the text [4]. Klingner, Vaughn, \& Boardman explain Reading comprehension is a multicomponent process, which is not merely that shows the interaction between the reader and what they previously understood as prior knowledge into the text and the variables contained text itself. This study also explains that reading comprehension is essential to understand the meaning of texts [5].

\section{Research relevant to Reading Comprehension}

In a study by Kramarski \& Feldman shows that the internet environment contributes significantly to motivating students towards English subjects (as a foreign language) in line. Still, no real contribution was found to substantially improve achievement in the fields of English reading comprehension and metacognitive awareness. This study revealed that metacognitive awareness did not affect the improvement in reading comprehension in English [6].

Hopewell believes understanding reading a second language often involves negotiation and shows understanding only through English. In other words, someone is asked to read in English, to discuss and negotiate to demonstrate knowledge by speaking or writing about texts in English. Hopewell believes understanding reading a second language often involves negotiation and shows understanding only through English. For example, students are asked to read to discuss and mediate to demonstrate knowledge by speaking or writing about texts in English. Another study, Huang \& Hong [8] revealed that English class interventions to improve ICT reading comprehension and their English because it encourages autonomy and the reason for starting to learn in a foreign language [7].

Yakub, Mayuasti, \& Ihksan suggested that English teachers implement SOAPS strategies in reading learning because it can guide students to learn the material actively and improve their reading comprehension [9]. SOAPS helps students to practice reading in English and understand it.

\section{The SOAPS strategy}

Why do teachers need to use SOAPS strategies in learning English in class? SOAPS Strategy is a strategy to help readers determine the purpose of an article. It means that students can not only understand the text but can also identify the elements of the text, and students can also find the purpose and purpose of the text. SOAPS helps students use analytical methods to understand the writer's expertise.

Cone [10] uses SOAPS strategies in teaching students to read informative stories. He gave an article, read it aloud, and asked students to narrate what they remembered about SOAPS. After students have been trained for a few days, SOAPS becomes a routine exercise, which is carried out at the beginning of class before moving to other learning activities on that day. I chose writing to teach related to hot and foreign issues because I wanted to broaden students' understanding of politics and culture to be broader.

One strategy that supports students analyzing social study texts as historians do is the SOAPStone approach. SOAPStone stands for speaker, event, audience, purpose, subject, and tone. This strategy can help students analyze text through sources and contextualization [11]. The cause of the document can be understood from the perspective of the author. And where the text was written. Students can do this by calculating who wrote the report and for what purpose [12]. In another study, the SOAPStone strategy was used to help students' skills to understand sources and adapt them to student contexts, and a historian's practice [13]. Shanahan [11], used the SOAPStone strategy with the ultimate goal being to be able to notify students to "source" their documents. The teacher asks them not only to identify the elements in SOAPStone. But also think about what is meant from the perspective and credibility of the text.

\section{The Five Steps to apply SOAPS strategy in this research}

The first, a teacher distributes the text to the students, and they start to read a piece of text without paying attention to some vital parts of information.

Second, a teacher shares with a student that they take a piece of the text and look for some aspects of the text.

Third, the teacher explains that when they examine parts of the text to understand the intent and purpose of the writer better. Teachers and students are active in asking questions about the meaning, who, and why the text was written. Finally, the topic of the text is read.

Fourth, a teacher asks students to identify different characters in a text and then answer the question by the students, thus discuss together.

Fifth, a teacher distributes SOAPS forms and explains SOAPS strategies as a way to help students set goals in a piece of text. S: subject (idea or theme of the text); O: chance (events in the text); A: audience (who is included in the text?); P: purpose (author's goal); S: speaker (who is speaking in the text). 


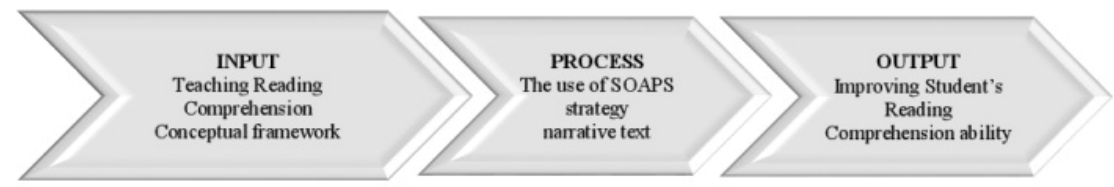

Fig 1. the three main components are input, process, and output

The picture above shows these three elements. The Input means related to narrative explanations delivered to students. The Process reveals the use of SOAPS strategies in the story text. Output means the ability to read student understanding.

\section{Research Method}

\section{Participants}

Sampling in this study was purposive sampling. The researcher chose class X1 IPS, which had 20 students as a sample. The reason the researchers chose this sample was the students' ability in reading comprehension, which was relatively low based on initial observations in this study.

\section{Research Design}

The method used in the research was a pre-experimental method with the one group pre-test, post-test design. The teacher gives a pre-test to students, and then they will provide treatment consisting of four meetings, and finally, they are given a post-test [14]. The design is illustrated as follows :

$$
\mathrm{H}_{1} \longrightarrow \mathrm{X} \longrightarrow \mathrm{H}_{2}
$$

While: $\mathrm{H}_{1}$ : pre-test; $\mathrm{X}$ : treatment; $\mathrm{H}_{2}$ : post-test

\section{Procedure}

The procedure of collecting data in the researcher as follows:

1. Pre-test

Researchers take initial measurements before receiving treatment. The researcher provides the text in the form of multiple choices consisting of 30 item numbers. It is intended to assess students' cognitive abilities in reading comprehension.

2. Treatment

The researcher has given the treatment to the students in many meetings, and the researcher used narrative text in reading comprehension. Teacher and student follow the instruction of the five steps to apply SOAPS strategy

3. Post-test

The treatment is done, so the same pre-test is repeated. The purpose is to know the outcome of the procedure.

\section{Data Analysis}

Data Data is processed statistically using SPSS version 22.0. Processed data are assessment data before treatment and data after treatment, T-test, and then analyzed descriptively in the discussion.

\section{$4 \quad$ Findings}

These findings were clarified follows:

1) Pre-test Analysis

Table 4.1. Classification and frequency of the students' pre-test

\begin{tabular}{lccc}
\hline Classification & Range & Frequency & Percentage \\
\hline Excellent & $91-100$ & 0 & 0 \\
Very good & $76-90$ & 1 & 5 \\
Good & $65-75$ & 3 & 15 \\
Fairly poor & $50-64$ & 8 & 40 \\
Fair & $35-49$ & 6 & 30 \\
Poor & $20-34$ & 2 & 10 \\
Very poor & $0-19$ & 0 & 0 \\
\hline
\end{tabular}




\begin{tabular}{lcc}
\hline Total & 20 & 100 \\
\hline
\end{tabular}

The data in Table 4.1 shows the percentage and frequency of students' initial assessment in reading comprehension that none of the students got a score of 91-100 (very good), while 1 (5\%) students were classified into 76-90 (very good), 3 (15\% ) the next student achieved a score of 65-75 (good), rather than 8 $(40 \%)$ students got a score of 50-64 (good enough), while in a reasonable score in the range of 35-49 there were also $6(30 \%)$ students, $2(10 \%)$ students get a score of 20-34 (bad), and none (0\%) students get a score of 0-19 (very poor). After the researcher gave an initial assessment in the first study, the researcher found that students' abilities were still low and were proven in how to answer questions. This result shows that students are also not familiar with foreign languages such as English.

2) Post-test

Table 4.2. Classification frequency of the students' post-test results.

\begin{tabular}{llcc}
\hline Classification & Range & Frequency & Percentage \\
\hline Excellent & $91-100$ & 1 & 5 \\
Very good & $76-90$ & 7 & 35 \\
Good & $65-75$ & 5 & 25 \\
Fairly good & $50-64$ & 7 & 35 \\
Fair & $35-49$ & 0 & 0 \\
Poor & $20-34$ & 0 & 0 \\
Very poor & $0-19$ & 0 & 0 \\
\hline Total & & 20 & 100 \\
\hline
\end{tabular}

Table 4.2 shows the percentage of post-test students' level and frequency in reading comprehension, of which 1 (5\%) students scored 91-100 (very good), while for excellent scores in the range of $76-90$, there were 7 (35\%) students. Then, 5 (25\%) students classed a score of 65-75 (good), 7 (35\%) students got a score of 50-64 (good enough), the category score 0-49 was absent. Thirteen students have grades between 65-100 and seven other students who score 50-64. Results after treatment (post-test) improved with the SOAPS strategy compared to scores before treatment (pre-test).

Table 4.3. The mean score of the students' pre-test and post-test

\begin{tabular}{cc}
\hline Test & Mean score \\
\hline Pre-test & 51.55 \\
Post-test & 71.30 \\
\hline
\end{tabular}

Table 4.3. Shows that the mean score of the students' before treatment was 51,55 while the mean score of the students' after treatment was 71,30. This study revealed that the post-test average scores of students experienced an increase compared to the average pre-test scores of students. Learning using SOAPS strategies can improve reading comprehension of Satria Makassar High School.

Table 4.4. Data statistic of pre-test and post-test

\begin{tabular}{|c|c|c|c|}
\hline & & Post-test & Pre-test \\
\hline \multirow[t]{3}{*}{$\mathrm{N}$} & Valid & 20 & 20 \\
\hline & Missing & & \\
\hline & & 0 & 0 \\
\hline \multicolumn{2}{|c|}{ Mean } & 71.30 & 51.55 \\
\hline \multicolumn{2}{|c|}{ Median } & 71.50 & 50.00 \\
\hline \multicolumn{2}{|c|}{ Mode } & $56^{\mathrm{a}}$ & $50^{\mathrm{a}}$ \\
\hline \multicolumn{2}{|c|}{ Std. Deviation } & 12.291 & 13.316 \\
\hline \multicolumn{2}{|c|}{ Variance } & 151.063 & 177.313 \\
\hline \multicolumn{2}{|c|}{ Range } & 43 & 46 \\
\hline \multicolumn{2}{|c|}{ Minimum } & 50 & 30 \\
\hline \multicolumn{2}{|c|}{ Maximum } & 93 & 76 \\
\hline \multicolumn{2}{|c|}{ Sum } & 1426 & 1031 \\
\hline
\end{tabular}


The total respondents in this study were twenty students. Table 4.4 shows the average score of student assessment before treatment (pre-test) is 51.55. The average score of students increased to 71.30. The minimum score of students at the initial assessment is 30 , while the minimum score after treatment is 50 . The maximum score of students at the initial assessment is 76 and increases after treatment with a maximum score of 93, while the number of post-tests is 1426 , and the number at the pre-test is 1031 .

The standard deviation of the initial assessment was 13.316, while the final standard deviation was 12.291, and the variance before treatment was 177.313 while the treatment was done is 151.063 . This research shows a significant improvement through SOAPS strategies applied in learning.

Table 4.4 shows that the t-test is higher than the t-table value $(36.420>2.093)$. The right statement is that there are significant differences between student outcomes before and after using the SOAPS strategy. The data in the table above shows that the t-test is higher than the t-table value $(36.420>2.093)$. Statistical data shows that there are significant differences between the initial results and the final results after using the SOAPS strategy.

\section{Discussion}

The use of new methods in learning is expected to improve the ability of students who are the ultimate goal of a teacher in the classroom. English is a subject that makes it difficult for students to learn because it is a foreign language to them. Safety pins, as well as English teachers, see the state of students and their needs, so they choose to learn methods that can improve students' reading comprehension. Early observations in the class show students are not interested and actively involved because of their initial view that English is difficult, so students are sometimes bored to learn.

The SOAPS strategy is applied in learning with the aim of increasing reading comprehension. Students in this learning must be relaxed and comfortable in learning. If the classroom conditions are enjoyable, aka students can focus more on learning. Reading comprehension becomes difficult for students if the lessons are not systematic, especially in understanding narrative texts. Students in learning cannot be given a paragraph consisting of difficult sentences. Therefore, the SOAPS treatment in the classroom gives students the opportunity to relax and enjoy the learning process in reading comprehension. Reading comprehension starts with the text and not the sentence. Students will more easily understand and develop their way of thinking to understand the meaning of the text and be guided by their teacher.

Data collected and statistics show an increase in students' reading comprehension. The use of SOAPS strategies in teaching reading can motivate students to read and understand well the meaning of the text being studied. Thus also increasing students' interest in reading other texts in learning English.

The low ability of reading comprehension in students can be overcome by the use of SOAPS strategies in language learning. Thus this strategy can also be used in learning other languages such as Indonesian, regional languages, and languages taught in schools. Learning activities with SOAPS strategies also affect the assessment of student attitudes related to student motivation and learning interest in learning English. Students are interested in learning to read comprehension. SOAPS strategies have proven to be effective in increasing students' reading comprehension

\section{Conclusion}

The need for students to improve their reading comprehension in English was answered in this study. SOAPS strategy is able to improve the reading comprehension of high school students. The initial assessment of low students can be improved by implementing a SOAPS strategy. The results of the average score of students increased from a value of 5.85 to an average value of students of 7.25. Thus the SOAPS strategy can also be expressed in lessons other languages besides English.

It can improve each student cognitively in reading comprehension. Testing through calculations using the SPPS version 22, shows that the results of the t-test are greater than t-table $=34.251>2.093$ at the 0.05 level. This means that the use of SOAPS strategies can significantly improve the understanding of reading texts in learning English in SMA Satria Makassar. 


\section{References}

[1] C. T. Linse and D. Nunan, Practical English language teaching: young learners. New York: McGrawHill/Contemporary, 2005.

[2] H. D. Brown, Language assessment: principles and classroom practices, Nachdr. New York: Longman, 2006.

[3] R. J. Baier, "Reading Comprehension And Reading Strategies," University of Wisconsin-Stout, Menomonie, WI, 2005.

[4] P. S. Westwood, What teachers need to know about reading and writing difficulties. Camberwell, Vic: ACER Press, 2008.

[5] J. K. Klingner, S. Vaughn, and A. Boardman, Teaching reading comprehension to students with learning difficulties. New York: Guilford Press, 2007.

[6] B. Kramarski and Y. Feldman, "Internet in the Classroom: Effects on Reading Comprehension, Motivation and Metacognitive Awareness," Educational Media International, vol. 37, no. 3, pp. 149-155, Jan. 2000.

[7] S. Hopewell, "Leveraging bilingualism to accelerate English reading comprehension," International Journal of Bilingual Education and Bilingualism, vol. 14, no. 5, pp. 603-620, Sep. 2011.

[8] Y.-N. Huang and Z.-R. Hong, "The effects of a flipped English classroom intervention on students' information and communication technology and English reading comprehension," Educational Technology Research and Development, vol. 64, no. 2, pp. 175-193, Apr. 2016.

[9] R. Yakub, M. Mayuasti, and M. K. Ihksan, "The Effect of Applying Speaker, Occasion, Audience, Purposes, and Subject (SOAPS) Strategy Toward Students' Reading Comprehension A Study at Eleventh Grade Students of SMA N 1 Hiliran Gumanti," Jurnal Ilmiah Mahasiswa STKIP PGRI Sumbar, pp. 1-4, 2015.

[10] J. K. Cone, "Detracked Ninth-Grade English: Apprenticeship for the Work and World of High School and Beyond," Theory Into Practice, vol. 45, no. 1, pp. 55-63, Feb. 2006.

[11] C. Shanahan, M. J. Bolz, G. Cribb, S. R. Goldman, J. Heppeler, and M. Manderino, Deepening What It Means to Read (and Write) Like a Historian: Progressions of Instruction across a School Year in an 11th Grade U.S. History Class. 2016.

[12] J. Platte, "The Impact of direct instruction on Students AP World History Document-Based Question," Goucher College, Dulaney Valley Road in Towson, Maryland, 2018.

[13] S. S. Wineburg, "On the Reading of Historical Texts: Notes on the Breach Between School and Academy," American Educational Research Journal, vol. 28, no. 3, pp. 495-519, Sep. 1991.

[14] L. R. Gay, Educational research: competencies for analysis and application, 5th ed. Upper Saddle River, N.J: Merrill, 1996. 